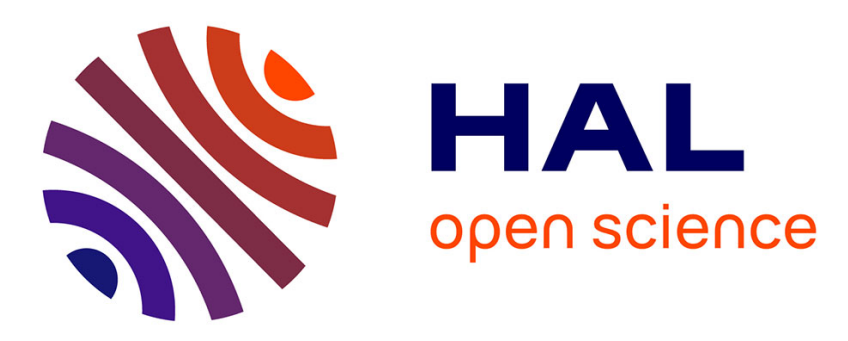

\title{
Factors associated with depression among homeless mothers. Results of the ENFAMS survey
}

\author{
M. Roze, S. Vandentorren, J Van-Der-Waerden, M. Melchior
}

\section{To cite this version:}

M. Roze, S. Vandentorren, J Van-Der-Waerden, M. Melchior. Factors associated with depression among homeless mothers. Results of the ENFAMS survey. Journal of Affective Disorders, 2018, 229, pp.314 - 321. 10.1016/j.jad.2017.12.053 . hal-01688315

\section{HAL Id: hal-01688315 \\ https://hal.sorbonne-universite.fr/hal-01688315}

Submitted on 19 Jan 2018

HAL is a multi-disciplinary open access archive for the deposit and dissemination of scientific research documents, whether they are published or not. The documents may come from teaching and research institutions in France or abroad, or from public or private research centers.
L'archive ouverte pluridisciplinaire $\mathbf{H A L}$, est destinée au dépôt et à la diffusion de documents scientifiques de niveau recherche, publiés ou non, émanant des établissements d'enseignement et de recherche français ou étrangers, des laboratoires publics ou privés. 


\title{
Research paper
}

\section{Factors associated with depression among homeless mothers. Results of the ENFAMS survey}

\author{
M. Roze ${ }^{\mathrm{a}, *}, \mathrm{~S}$. Vandentorren ${ }^{\mathrm{b}}, \mathrm{J}$. Van-Der-Waerden ${ }^{\mathrm{a}}$, M. Melchior ${ }^{\mathrm{a}}$ \\ a Sorbonne Universités, UPMC Univ Paris 06, INSERM, Institut Pierre Louis d'Épidémiologie et de Santé Publique (UMRS 1136), Équipe de Recherche en Épidémiologie Sociale, F75012, Paris, \\ France \\ ${ }^{\mathrm{b}}$ Direction des régions, Santé Publique France, France
}

\section{A R T I C L E I N F O}

Keywords:

Homeless

Women's mental health

Depression

\begin{abstract}
A B S T R A C T
Purpose: Women are disproportionately likely to suffer from depression. This is especially true for those who experience socioeconomic hardship, such as homelessness. In France, among homeless mothers many are migrant. However, it is not clear whether risk factors associated with depression are specific for this group or the same as in the general population. Our objective was to describe socio-demographic, relational, living and housing conditions and health factors associated with depression among homeless mothers.

Methods: The ENFAMS survey, conducted via face-to-face bilingual interviews with a representative sample of homeless families in the Paris region (January-May 2013, $\mathrm{n}=733$ mothers). Mothers reported their socio-demographic characteristics, housing conditions including residential mobility, as well as physical and mental health. Depression was ascertained using the Composite International Diagnostic Interview (CIDI). Factors associated with mother's depression were studied in weighted Poisson regression models with robust error variance.

Results: The prevalence of depression among participating mothers was $28.8 \%$. In multivariate analyses, depression was associated with fluency in French ( $\mathrm{PR}=1.8895 \%$ CI $1.40 ; 2.51)$, suicide risk (PR $=2.26,95 \%$ CI 1.82; 2.82), post-traumatic stress disorder ( $\mathrm{PR}=1.97,95 \% \mathrm{CI} 1.50 ; 2.60)$, and unmet health needs $(\mathrm{PR}=1.68,95 \%$ CI 1.09; 2.57).

Conclusions: Homeless mothers have high levels of depression and associated psychiatric comorbidities. Associated risk factors appear to be both specific for this group and shared with mothers in the general population. Improvements in the monitoring of mental health difficulties as well as access to appropriate medical care in this vulnerable population may help improve health and social outcomes.
\end{abstract}

\section{Introduction}

Depression is a major public health problem, especially among women. In France, $7.2 \%$ of women in the general population experience major depression at any point in time Chan Chee et al., 2009). Although treatable, depression often goes unnoticed and underdiagnosed (Grant et al., 2013; Suglia et al., 2011). Risk factors of depression include biological as well as environmental risk factors which sometimes interact (Gertz et al., 2011; Caspi et al., 2005; Gillespie et al., 2005; Kendler et al., 2002). Specifically, genetic vulnerability (e.g. the serotonin transporter gene) (Caspi et al., 2003; Eley et al., 2004) alone or in interaction with the environment (Gertz et al., 2011; Caspi et al., 2005; Gillespie et al., 2005; Kendler et al., 2002, 2005; York et al.,
2005), neurobiological factors (e.g. stress can alter the development of the hypothalamic-pituitary-adrenal axis, hypothalamic and extrahypothalamic corticotropin releasing hormone, monoaminergic, and gamma-aminobutyric acid/benzodiazepine systems) (Kaufman et al., 2000; Phillips et al., 2003a, 2003b), personality traits (Boyce et al., 1991), life stress (Gillespie et al., 2005; Monroe and Harkness, 2005; de Kloet et al., 2005; Willner, 2017; Kendler et al., 2003; Kessler, 1997), a disturbed family environment (e.g. prenatal stress, parental care, overprotection and disciplinary practices) (Huizink et al., 2004; Parker, 1979; Holmes and Robins, 1988), exposure to violence (Caspi et al., 2002), somatic health problems (e.g. diabetes) (Holt et al., 2014), substance abuse (Caspi et al., 2005; Kessler et al., 1996) represent the main sources of risk. Poverty, defined as economic and material deprivation, is associated with high levels of stress and negative life

\footnotetext{
* Corresponding author.

Email address: mathilde.rz@gmail.com (M. Roze)
} 
circumstances (Cutler and Nolen-Hoeksema, 1991; Kessler and Magee, 1993), pervasive powerlessness, and social isolation (Henderson, 1992), all known to contribute to emotional distress and depression (Goodman et al., 2009; Gilbert and Allan, 1998; Brown et al., 1995). Mothers who experience material hardship and particularly homelessness appear disproportionately exposed to several of these risk factors and may be additionally exposed to specific situations of vulnerability, which contribute to their risk of depression. This makes homeless mothers an especially vulnerable group (Zabkiewicz et al., 2014; Bassuk et al., 1998; Weinreb et al., 2006; Laporte et al., 2010) for this mental health problem (half of homeless mothers suffered from depression).

Families are currently the fastest growing segment of the homeless population (Bassuk et al., 2014). In 2013, an estimated 10,280 homeless families (approximately 35,000 people including 17,660 children) were accommodated by social services in the Paris region (Vandentorren et al., 2016). These estimates do not take into account families housed by friends or relatives, implying that the overall number of persons without stable accommodation is probably higher. It is important to note that a majority of these families are migrant. This recent increase (Guyavarch and Le Mener, 2010) is due to several factors. First, levels of poverty and the cost of living in the Paris region simultaneously increased in recent years, amplifying difficulties in access to housing, especially among vulnerable groups. Second, increasing numbers of families who apply for political asylum are referred to homeless shelters due to insufficient capacity in specific facilities, which automatically leads to a higher number of homeless persons. As in many large European cities, in Paris the proportion of persons who have asked for political asylum and are homeless has increased (38\% in 2001, 52\% in 2012) (An overview of housing exclusion in europe, 2015).

Given these changing circumstances, there is need to update knowledge about characteristics of homeless mothers, specifically in terms of depression, the most frequent mental health problem in this population (Laporte et al., 2015). Our aims were: 1) to describe the prevalence of depression in homeless mothers; 2) to identify socio-demographic and health characteristics associated with depression in this vulnerable group.

\section{Materials and methods}

\subsection{Sample}

The ENFAMS survey (a French acronym for "ENfants et FAMilles Sans logement" - "Homeless children and families") (Vandentorren et al., 2016) was conducted by the Observatoire du Samu Social (Observatory of the Social Emergency Service - a non-governmental organization which provides shelter to persons who are homeless in Paris area) from January to May 2013. The aim of the study was to describe the socio-demographic characteristics and health of homeless families in the Paris region (approximately 12 million inhabitants). Following guidelines established by France's National Institute of Statistics (INSEE), a person is considered to be homeless on any given day if he or she spent the previous night on the street or in a sheltered accommodation. In our study, inclusion criteria were: to be a member of a family composed by an adult and at least one child under 13 years of age, to speak one of the 17 survey languages and to be accommodated in: 1) emergency shelters that are generally short-term and provide only basic services (e.g. breakfast); 2) social hotel; 3) long-term rehabilitation centers in which persons can stay up to several months and which provide a larger number of services (e.g. access to a kitchen); 4) reception centers for asylum-seekers) (Buckner et al., 2004). Emergency shelters and social hotels are considered to be short-term, whereas long-term rehabilitation centers and centers for asylum-seekers are long-term.
First, among the 796 accommodations for homeless persons in the region at the time of the survey, 251 were randomly selected stratifying on facility type ( $82 \%$ participation rate). Second, families with at least one child under 13 years of age were randomly selected: 801 (65\% participation) took part in the study (Vandentorren et al., 2016). Participants were identified using time-location sampling (Vandentorren et al., 2016; Leon et al., 2015).

Families which did not participate in the ENFAMS survey were characterized by younger maternal age (33 vs. 38 years), a higher proportion of men (15.3 vs. $4.6 \%$ ), and a higher proportion of families with two or more children (31.7 vs. $23.1 \%$ ) (Vandentorren et al., 2016). Reasons most frequently cited to explain non-participation were: lack of interest (17\%), lack of time (14\%) or the other parent's lack of written consent (11\%).

The ENFAMS study was approved by the French National Committee overseeing ethical data collection (CNIL), and two ethics boards (the Comité de Protection des Personnes - CPP - in Île-de-France and the Comité Consultatif sur le Traitement de l'Information en matière de Recherche dans le domaine de la Santé - CCTIRS).

\subsection{Measures and questionnaires}

Study data were collected in face-to-face interviews conducted by bilingual trained interviewers and psychologists in 17 different languages. Additionally, blood samples and anthropometric measures were collected by study nurses.

The study outcome was depression in the preceding 12 months ascertained using the Composite International Diagnostic Interview (Kessler et al., 1998).

Based on prior scientific literature, factors examined as potentially associated with depression included:

- socio-demographic and familial characteristics: age; region of birth (Europe vs. not Europe); administrative status (French citizenship/resident status in France, undocumented, asylum seeker or with a resident permit); family status (i.e. living with a partner, number of children and their age); exposure to domestic violence in the preceding 12 months ascertained with 14 questions used by the National Institute of Demography (INED) (Hamel et al., 2014) (e.g. "did your spouse or partner/ex-partner prevent you from accessing household money for the everyday expenses? Threaten to target your children or to take your children away? Insult or abuse you?", yes vs. no); contacts with family (once or more per year: yes vs. no); employment/schooling status (yes or no); educational level ( $<$ high school degree: yes vs. no); monthly income ( $\leq$ poverty line of 964 euros/month/pers yes vs. no); health insurance (complete, incomplete, vs. none); food insecurity in the preceding 12 months (assessed using the French version of the US Household Food Security Module (Martin-Fernandez et al., 2013; Radimer, 2002); yes vs. no); fluency in French (yes vs. no); social support (ascertained by two items investigating whether the person knew someone living in France at the time of arrival and whether this person helped: yes vs. no); material support from an non-governmental organization, friends or family (e.g. food vouchers, clothes, money: yes vs. no); reason for departure from country of origin (violent cause: yes vs. no);

- living and housing conditions: ever spent the night on the street (yes vs. no); time since the family arrived in France (dichotomized at the median value: $<3$ years: yes vs. no) and time since homelessness (assessed with the question: "In France, when did you find yourself for the first time homeless, in a homeless shelter (CHRS, CADA ...) or in a hotel that an association paid for?", dichotomized at the median value: $<2$ years: yes vs. no); type of shelter (short vs. long-term); residential instability (i.e. time in the last shelter, dichotomized at 
the median value: $<6$ months: yes vs. no); housing quality ( $\leq 2$ persons per room: yes vs. no);

- physical health characteristics: serious health problem(s) that disrupt daily life (yes vs. no); anemia (ascertained in study blood samples: yes vs. no); obesity measured by study nurses (BMI > 30: yes vs. no); pregnancy at the time of the interview (yes vs. no); female circumcision (yes vs. no); and subjective unmet health needs, in the last 12 months (yes vs. no);

- mental health characteristics: lifetime suicide risk ascertained using the MINI (Mini International Neuropsychiatric Interview) (yes vs. no) (Sheehan et al., 1998); Post Traumatic Stress Disorder (PTSD) ascertained using the MINI (Sheehan et al., 1998) (yes vs. no);"Concomittant PTSD" and "Past history of PTSD".

\subsection{Statistical analyses}

Our analyses were based on a sample of 733 mothers with complete depression data. Missing data (maximum 13.5\% for domestic violence) were imputed using Multiple Imputations by Chained Equations (MICE), based on a Monte-Carlo Markov Chain algorithm (van Buuren and Groothuis-Oudshoorn, 2011). First, based on prior scientific literature we identified variables potentially associated with maternal depression. Second, we performed univariate analyses to describe the prevalence of depression in our study population. Third, to identify characteristics associated with depression, we used weighted Poisson regression with robust error variance (Zou, 2004). This yielded Prevalence Ratios (PR) with 95\% Confidence Intervals. All the variables significantly associated with the depression in univariate analyses $(\mathrm{p}<0.05)$ (Table 1 ) were included in the multivariate analysis (Table 2).

Post-traumatic stress disorder was one of strongest predictors for depression in our study. Some risk factors were similar in depression and in PTSD. In secondary analysis, we used chi-square analyses to compare depressed mothers who had "Concomittant PTSD", "Past history of PTSD" to those who did not experience PTSD.

All statistical analyses were performed with R, used the "survey" weighting package to account for study design.

\section{Results}

\subsection{Study population characteristics}

Mother's characteristics are shown in Table 1. Briefly, mother's median age at the time of the study was 31.0 years (Q1 27.0 - Q3 36.0), $79.0 \%$ were born outside Europe, $53 \%$ of mothers were single parents, $23.7 \%$ experienced domestic violence, $20.6 \%$ living with at least 3 children, $42.7 \%$ were fluent in French, $41.8 \%$ had social support and $27.7 \%$ left their country of origin due to violence.

In terms of mental health, $28.8 \%$ of mothers suffered from depression, $18.3 \%$ were at risk of suicide and $16.7 \%$ had signs of post-traumatic stress disorder. Among mothers with depression, 36.9\% had PTSD that began more than 12 months prior to the study, $11.5 \%$ had a history of PTSD anterior to the study and 51.6\% never had PTSD.

\subsection{Univariate and multivariate analyses: factors associated with depression}

As shown in Table 1, factors associated with mother's depression were the following: single parenthood ( $P R=1.5995 \%$ CI $1.21 ; 2.08)$, absence of contacts with family (PR $=1.4995 \%$ CI 1.03; 2.17), higher educational level (PR $=1.57$ 95\% CI 1.17; 2.11), food insecurity (PR $=1.5095 \%$ CI $1.11 ; 2.04)$, fluency in French $(\mathrm{PR}=2.0795 \% \mathrm{CI}$ $1.57 ; 2.74)$, a prior experience of spending a night on the street $(\mathrm{PR}=$ $1.5395 \%$ CI 1.15; 2.04), arrival in France in the preceding 3 years (PR
$=1.3995 \%$ CI 1.09; 1.79), homelessness for less than 2 years (PR $=1.33$ IC95\% CI 1.03; 2.72), residential instability (PR $=1.5095 \%$ CI 1.12; 2.01), lifetime suicide risk ( $\mathrm{PR}=3.1295 \%$ CI 2.56; 3.79), post-traumatic stress disorder in the preceding 12 months ( $\mathrm{PR}=$ $2.8995 \%$ CI $2.20 ; 3.79$ ) and unmet health needs ( $\mathrm{PR}=1.8995 \% \mathrm{CI}$ $1.30 ; 2.76)$;

In the multivariate analysis (Table 2), adjusting for mother's age, factors associated with depression were: mother's high fluency in French $(\mathrm{PR}=1.8895 \% \mathrm{CI} 1.40 ; 2.51)$, lifetime suicide risk ( $\mathrm{PR}=2.2695 \% \mathrm{CI}$ 1.82; 2.82), post-traumatic stress disorder in the preceding 12 months $(\mathrm{PR}=2.9795 \%$ CI $2.50 ; 3.60)$ and unmet health needs $(\mathrm{PR}=$ 1.68 95\% CI 1.09; 2.57);

In our study, mothers from Sub-Saharan Africa were more fluent in French that women from other geographical regions, which could explain the association between fluency in French and depression, but we found no statistically significant interactions between Sub-Saharan origin and fluency in French with regard to depression.

\subsection{Depression and PTSD}

As post-traumatic stress disorder was one of strongest predictors for depression, we used chi- square analyses to compare depressed women who had "Concomittant PTSD", "Past history of PTSD" to those who did not experience PTSD. As shown in Table 3 we found significant differences in the prevalence of the following variables: departure from country of origin for a violent cause $(\mathrm{p}<0001)$; absence of health insurance ( $\mathrm{p}=0.035)$; lack of social support $(\mathrm{p}<0.001)$; at least one night spent on the street $(\mathrm{p}=0.025)$; serious health problems $(\mathrm{p}=0.030)$; pregnancy $(p=0.007)$; and lifetime suicide risk $(p=0.039)$.

\section{Discussion}

\subsection{Main findings}

In our study, homeless mothers reported high levels of depression (28.8\%). Key associated factors were fluency in French $(\mathrm{PR}=$ 1.88), lifetime suicide risk ( $P R=2.26$ ), post-traumatic stress disorder $(P R=2.97)$ and unmet health needs $(P R=1.68)$. Mothers who were depressed and had post-traumatic stress disorder experienced especially high levels of health and social difficulties. Our results contribute to the scientific literature showing high levels of mental health difficulties among mothers who experience homelessness and suggest that some risk factors (e.g. high levels of comorbidity with post-traumatic stress disorder in this migrant population) (Roze et al., 2017) are specific to this population. It is important to note that most families in our study were migrants, therefore we are not able to distinguish the contribution of characteristics specific to migrants from those of homelessness.

\subsection{Comparison with past studies}

In prior studies, the prevalence of depression in homeless mothers was estimated to be 52-58\% (Zabkiewicz et al., 2014; Weinreb et al., 2006). Thus the prevalence we report is on the lower end of prior estimates. This may be because in the Paris region homelessness is primarily related to lack of access to affordable housing as well as recent migration, which was not the case of studies conducted in the United States among persons that were homeless for long periods of time.

It may also be that some mothers were reluctant to acknowledge negative feelings or an inability to cope, thinking that this may negatively affect their children and reflect poorly upon them as mothers. As depression was particularly prevalent among single mothers compared to those living with a partner they additionally, may worry about losing parental rights. 
Table 1

Characteristic associated with depression in homeless women in the Paris region (ENFAMS survey 2013, $\mathrm{n}=733$, univariate Poisson regression analysis).

\begin{tabular}{|c|c|c|c|c|c|c|c|}
\hline & & \multicolumn{3}{|c|}{ Description } & \multicolumn{3}{|c|}{ Univariate analysis } \\
\hline & & $\begin{array}{l}\text { All } \\
\text { mothers }\end{array}$ & $\begin{array}{l}\text { Mothers with } \\
\text { depression }\end{array}$ & $\begin{array}{l}\text { Mothers } \\
\text { without } \\
\text { depression }\end{array}$ & $\begin{array}{l}\text { Depression } \\
\text { prevalence }\end{array}$ & $\begin{array}{l}\text { Prevalence } \\
\text { Ratio }\end{array}$ & $95 \% \mathrm{CI}$ \\
\hline \multicolumn{8}{|c|}{ SOCIO DEMOGRAPHIC CHARACTERISTICS } \\
\hline \multirow[t]{2}{*}{ Age } & [17-27] yo & 25.6 & 26.8 & 25.2 & 30.1 & ref & \\
\hline & [27-57] yo & 74.4 & 73.2 & 74.8 & 28.4 & 0.9 & {$[0.67 ; 1.32]$} \\
\hline \multirow[t]{2}{*}{ Region of birth } & Europe & 21.0 & 19.1 & 21.8 & 26.1 & ref & \\
\hline & Outside Europe & 79.0 & 80.9 & 78.2 & 29.5 & 1.1 & {$[0.80 ; 1.59]$} \\
\hline \multirow[t]{4}{*}{ Administrative status } & $\begin{array}{l}\text { French/legal } \\
\text { administrative } \\
\text { situation }\end{array}$ & 20.1 & 23.2 & 18.8 & 33.3 & ref & \\
\hline & Undocumented & 44.4 & 37.6 & 47.2 & 24.3 & 0.7 & {$[0.51 ; 1.04]$} \\
\hline & Asylum seeker & 11.6 & 9.3 & 12.6 & 23.4 & 0.7 & {$[0.44 ; 1.12]$} \\
\hline & Resident permit & 23.9 & 29.9 & 21.4 & 36.0 & 1.1 & {$[0.73 ; 1.60]$} \\
\hline \multirow[t]{2}{*}{ Family status } & Two parent family & 47.0 & 35.9 & 51.5 & 22.0 & ref & \\
\hline & Single parenthood & 53.0 & 64.1 & 48.5 & 34.8 & 1.6 & {$[1.21 ; 2.08]$} \\
\hline \multirow{2}{*}{$\begin{array}{l}\text { Exposure to domestic } \\
\text { violence }\end{array}$} & No & 76.3 & 72.1 & 78.1 & 27.4 & ref & \\
\hline & Yes & 23.7 & 27.9 & 21.9 & 33.4 & 1.2 & {$[0.88 ; 1.69]$} \\
\hline \multirow{2}{*}{$\begin{array}{l}\text { Mother living with at } \\
\text { least one child under } 1 \\
\text { year }\end{array}$} & No & 68.9 & 64.2 & 70.9 & 26.8 & ref & \\
\hline & Yes & 31.1 & 35.8 & 29.1 & 33.2 & 1.2 & {$[0.98 ; 1.57]$} \\
\hline \multirow{2}{*}{$\begin{array}{l}\text { Mother living with at } \\
\text { least } 3 \text { children }\end{array}$} & No, 2 child max & 79.4 & 82.3 & 78.2 & 29.8 & ref & \\
\hline & Yes, 3 or more & 20.6 & 17.7 & 21.8 & 24.7 & 0.8 & {$[0.60 ; 1.15]$} \\
\hline \multirow[t]{2}{*}{ Contacts with family } & $\begin{array}{l}\text { Yes, one or more } \\
\text { communication by } \\
\text { year }\end{array}$ & 94.4 & 91.8 & 95.5 & 28.0 & ref & \\
\hline & No, never & 5.6 & 8.2 & 4.5 & 41.8 & 1.5 & {$[1.03 ; 2.17]$} \\
\hline \multirow[t]{2}{*}{ Employment status } & $\begin{array}{l}\text { Employed or in } \\
\text { schooling }\end{array}$ & 21.3 & 24.3 & 20.1 & 32.8 & ref & \\
\hline & $\begin{array}{l}\text { Neither employed } \\
\text { nor in schooling }\end{array}$ & 78.7 & 75.7 & 79.9 & 27.7 & 0.8 & {$[0.62 ; 1.15]$} \\
\hline \multirow[t]{2}{*}{ Educational level } & $<$ high school & 49.3 & 38.0 & 53.9 & 22.4 & ref & \\
\hline & $\geq$ high school & 50.7 & 62.0 & 46.1 & 35.1 & 1.6 & {$[1.17 ; 2.11]$} \\
\hline \multirow[t]{2}{*}{ Usual monthly income } & Above poverty line & 3.2 & 3.7 & 3.1 & 32.4 & ref & \\
\hline & Below poverty line & 96.8 & 96.3 & 96.9 & 28.7 & 0.9 & {$[0.38 ; 2.09]$} \\
\hline \multirow[t]{3}{*}{ Health insurance } & Complete & 66.1 & 65.9 & 66.1 & 28.5 & ref & \\
\hline & Incomplete & 12.0 & 13.3 & 11.5 & 32.6 & 1.1 & {$[0.79 ; 1.65]$} \\
\hline & None & 21.9 & 20.8 & 22.4 & 27.5 & 1.0 & {$[0.69 ; 1.35]$} \\
\hline \multirow[t]{2}{*}{ Food insecurity } & No & 45.8 & 35.5 & 50.0 & 22.6 & ref & \\
\hline & Yes & 54.2 & 64.5 & 50.0 & 34.0 & 1.5 & {$[1.11 ; 2.04]$} \\
\hline \multirow[t]{2}{*}{ Fluency in French } & No & 57.3 & 39.3 & 64.6 & 19.7 & ref & \\
\hline & Yes & 42.7 & 60.7 & 35.4 & 41.0 & 2.1 & {$[1.57 ; 2.74]$} \\
\hline \multirow[t]{2}{*}{ Social support } & Yes & 41.8 & 43.4 & 41.3 & 30.7 & ref & \\
\hline & No & 58.2 & 56.6 & 58.7 & 27.3 & 0.9 & {$[0.66 ; 1.20]$} \\
\hline Material support from an & Yes & 71.9 & 72.0 & 71.8 & 28.9 & ref & \\
\hline & No & 28.1 & 28.0 & 28.2 & 28.5 & 1.0 & {$[0.73 ; 1.34]$} \\
\hline Reason for departure & Not a violent cause & 72.3 & 69.9 & 73.2 & 27.8 & ref & \\
\hline & Violent cause & 27.7 & 30.1 & 26.8 & 31.3 & 1.1 & {$[0.87 ; 1.45]$} \\
\hline LIVING AND HOUSING C & TIONS & & & & & & \\
\hline Ever spend the night in & No & 85.9 & 80.0 & 88.3 & 26.8 & ref & \\
\hline & Yes & 14.1 & 20.0 & 11.7 & 41.0 & 1.5 & {$[1.15 ; 2.04]$} \\
\hline Time since the family & $>3$ years & 52.1 & 43.8 & 55.2 & 23.1 & ref & \\
\hline & $\leq 3$ years & 47.9 & 56.2 & 44.8 & 32.2 & 1.39 & {$[1.09 ; 1.79]$} \\
\hline Time since homeless & $>2$ years & 47.0 & 40.1 & 49.8 & 24.5 & ref & \\
\hline & $\leq 2$ years & 53.0 & 59.9 & 50.2 & 32.6 & 1.33 & {$[1.03 ; 1.72]$} \\
\hline Type of shelter & Short time shelter & 79.2 & 79.8 & 78.9 & 29.0 & ref & \\
\hline & Long time shelter & 20.8 & 20.2 & 21.1 & 27.8 & 1.0 & {$[0.73 ; 1.25]$} \\
\hline Residential instability & No & 61.3 & 51.4 & 65.3 & 24.1 & ref & \\
\hline & Yes & 38.7 & 48.6 & 34.7 & 36.2 & 1.5 & {$[1.12 ; 2.01]$} \\
\hline Housing quality & $\leq 2$ pers per room & 43.8 & 47.0 & 42.5 & 30.9 & ref & \\
\hline & $>2$ pers per room & 56.2 & 53.0 & 57.5 & 27.2 & 0.9 & {$[0.68 ; 1.14]$} \\
\hline PHYSICAL HEALTH CHA & ERISTICS & & & & & & \\
\hline
\end{tabular}




\begin{tabular}{|c|c|c|c|c|c|c|c|}
\hline & & \multicolumn{3}{|c|}{ Description } & \multicolumn{3}{|c|}{ Univariate analysis } \\
\hline & & $\begin{array}{l}\text { All } \\
\text { mothers }\end{array}$ & $\begin{array}{l}\text { Mothers with } \\
\text { depression }\end{array}$ & $\begin{array}{l}\text { Mothers } \\
\text { without } \\
\text { depression }\end{array}$ & $\begin{array}{l}\text { Depression } \\
\text { prevalence }\end{array}$ & $\begin{array}{l}\text { Prevalence } \\
\text { Ratio }\end{array}$ & $95 \% \mathrm{CI}$ \\
\hline \multirow{2}{*}{$\begin{array}{l}\text { Serious health } \\
\text { problem(s) that has(ve) } \\
\text { disrupted daily life }\end{array}$} & No & 70.0 & 63.1 & 72.8 & 25.9 & ref & \\
\hline & Yes & 30.0 & 36.9 & 27.2 & 35.6 & 1.4 & {$[0.99 ; 1.90]$} \\
\hline \multirow[t]{2}{*}{ Anemia } & No & 75.0 & 75.0 & 75.0 & 28.8 & ref & \\
\hline & Yes & 25.0 & 25.0 & 25.0 & 28.7 & 1.0 & {$[0.69 ; 1.43]$} \\
\hline \multirow[t]{2}{*}{ Obesity } & No & 64.6 & 64.3 & 64.7 & 28.9 & ref & \\
\hline & Yes & 35.4 & 35.7 & 35.3 & 28.7 & 1.0 & {$[0.71 ; 1.39]$} \\
\hline \multirow[t]{2}{*}{ Pregnancy } & No & 92.9 & 91.2 & 93.6 & 28.3 & ref & \\
\hline & Yes & 7.1 & 8.8 & 6.4 & 35.8 & 1.3 & {$[0.87 ; 1.85]$} \\
\hline \multirow[t]{2}{*}{ Female circumcision } & No & 79.7 & 79.2 & 79.9 & 28.8 & ref & \\
\hline & Yes & 20.3 & 20.8 & 20.1 & 28.6 & 1.0 & {$[0.70 ; 1.41]$} \\
\hline \multirow{2}{*}{$\begin{array}{l}\text { Unmet health needs, in } \\
\text { the preceding } 12 \text { months }\end{array}$} & No & 92.2 & 86.2 & 94.6 & 26.9 & ref & \\
\hline & Yes & 7.8 & 13.8 & 5.4 & 51.0 & 1.9 & {$[1.30 ; 2.76]$} \\
\hline \multicolumn{8}{|c|}{ MENTAL HEALTH CHARACTERISTICS } \\
\hline \multirow[t]{2}{*}{ Lifetime suicide risk } & No & 81.7 & 58.8 & 90.9 & 20.7 & ref & \\
\hline & Yes & 18.3 & 41.2 & 9.1 & 64.7 & 3.1 & {$[2.56 ; 3.79]$} \\
\hline \multirow{2}{*}{$\begin{array}{l}\text { PTSD, in the preceding } \\
12 \text { months }\end{array}$} & No & 83.3 & 63.1 & 91.5 & 21.9 & ref & \\
\hline & Yes & 16.7 & 36.9 & 8.5 & 63.2 & 2.9 & {$[2.20 ; 3.79]$} \\
\hline \multirow{3}{*}{$\begin{array}{l}\text { "Story" of Post Traumatic } \\
\text { Stress Disorder }\end{array}$} & Concomittant PTSD & 16.7 & 36.9 & 8.5 & - & - & \\
\hline & Past history of PTSD & 7.2 & 11.5 & 5.5 & - & - & \\
\hline & No PTSD & 76.1 & 51.6 & 86.0 & - & - & \\
\hline
\end{tabular}

In ENFAMS survey 53.0\% of mothers are single parenthood, among mothers with depression they are $64.1 \%$, among mothers without depression they are $48.5 \%$.

Among single parenthood mothers, $34.8 \%$ suffer of depression. Single parenthood mothers have a prevalence of depression 1.6 time higher than mothers in two parent family.

It may also be that, although the CIDI used in our study has been validated in different sociocultural circumstances, it underestimates the prevalence of depression in multicultural populations (Baubet and Moro, 2013). It has been noted that in some countries, depression is not a culturally acknowledged condition. Many cultures have no word for depression, and describe their feeling with expression of somatic complains (i.e. expression meaning "half of my body collapsed" or body weakness (Sweetland et al., 2014)).

In particular, differences in the validity of our depression measure may partly explain why we observed higher levels of symptoms among mothers who are fluent in French than among those who were not. Some prior studies reported similar findings but in others mothers who were not fluent in their host country tongue were especially vulnerable (Gupta et al., 2013; Janssen-Kallenberg et al., 2017; Ünlü Ince et al., 2014; Bernstein et al., 2011). Additional research, validating measures of psychological distress and depression among recent immigrants - particularly from Sub-Saharan Africa - would be valuable (Pannetier et al., 2017). Other studies have found that some measures of depression yield high levels of false positive results in Sub-Saharan HIV-positive women (Tsai, 2015).

The main determinant of mother's depression in our study was the experience of other mental health difficulties, such as lifetime suicide risk and post-traumatic stress disorder. This highlights the high levels of exposure to violence among mothers who experience homelessness (Bassuk, 2017; Bassuk et al., n.d. ; Vostanis et al., 2001). Our study was largely composed of mothers who are non-French, yet we are not in a position to determine whether the violent and traumatic experiences they experienced occurred in their country of origin, during the process of migration, or after they arrived in France.

\subsection{Depression and post traumatic stress disorder}

As in other studies, we observed a high co-occurrence of depression with post-traumatic stress disorder (Roze et al., 2017). It may be that both disorders have a joint underlying vulnerability (Roze et al., 2017; O'Donnell et al., 2004; Breslau et al., 2000). Our secondary analysis indicates that among mothers with depression and concomitant PTSD, $51.8 \%$ have left their country for a violent cause, suggesting that in most cases, symptoms of post-traumatic stress disorder may predate depression. Moreover, mothers experiencing both depression and PTSD have more vulnerability factors (lack of health insurance, insufficient social support, serious health problems and suicide risk) than those who experienced depression only, suggesting that an accumulation of health and social risks among some homeless mothers has important impacts in terms of mental health.

As in other studies, unmet health needs appeared to be substantially more frequent among mothers who were depressed than among those who were not (Alltag et al., 2017). This may reflect mother's difficulty to recognize their health needs as well as attend to them, and suggests that specific health outreach activities or screening integrated with other types of services provided to homeless families may help identify mothers in need of specific support (Lee et al., 2010; Vuillermoz et al., 2017). France is characterized by universal health insurance that covers the entire population, including undocumented migrants. Nevertheless, mothers with mental health difficulties may experience particular barriers in their access to the health system (e.g. insufficient information about health care providers). Thus, immigrants and persons who are homeless may benefit from systematic medical consultations that identify and address their somatic and mental health problems.

Contrary to other studies, we did not find that mother's educational level (Bernstein, 2001), poverty (Bernstein, 2001; Brown and Moran, 1997), marital status (Bernstein, 2001), social support (Bassuk and 
Table 2

Characteristic associated with depression in homeless women in the Paris region (ENFAMS survey 2013, $\mathrm{n}=733$, multivariate Poisson regression analysis).

\begin{tabular}{|c|c|c|c|}
\hline & & \multicolumn{2}{|c|}{ Multivariate analysis } \\
\hline & & Prevalence & \\
\hline & & Ratio & $95 \% \mathrm{CI}$ \\
\hline \multicolumn{4}{|c|}{ SOCIO DEMOGRAPHIC CHARACTERISTICS } \\
\hline \multirow[t]{2}{*}{ Age } & [17-27] yo & ref & \\
\hline & [27-57] yo & 1.11 & {$[0.79 ; 1.56]$} \\
\hline \multirow[t]{2}{*}{ Family status } & Two parent family & ref & \\
\hline & Single parenthood & 1.13 & {$[0.86 ; 1.49]$} \\
\hline \multirow[t]{2}{*}{$\begin{array}{l}\text { Contacts with } \\
\text { family }\end{array}$} & $\begin{array}{l}\text { Yes, one or more } \\
\text { communication by } \\
\text { year }\end{array}$ & ref & \\
\hline & No, never & 1.34 & {$[0.88 ; 2.02]$} \\
\hline \multirow[t]{2}{*}{ Educational level } & $<$ high school & ref & \\
\hline & $\geq$ high school & 1.16 & {$[0.86 ; 1.58]$} \\
\hline \multirow[t]{2}{*}{ Food insecurity } & No & ref & \\
\hline & Yes & 1.29 & {$[0.95 ; 1.74]$} \\
\hline \multirow{2}{*}{$\begin{array}{l}\text { Fluency in } \\
\text { French }\end{array}$} & No & ref & \\
\hline & Yes & 1.88 & {$[1.40 ; 2.51]$} \\
\hline \multicolumn{4}{|c|}{ LIVING AND HOUSING CONDITIONS } \\
\hline \multirow{2}{*}{$\begin{array}{l}\text { Ever spend the } \\
\text { night in the } \\
\text { street }\end{array}$} & No & ref & \\
\hline & Yes & 1.12 & {$[0.85 ; 1.48]$} \\
\hline \multirow{2}{*}{$\begin{array}{l}\text { Time since the } \\
\text { family arrived in } \\
\text { France }\end{array}$} & $>3$ years & ref & \\
\hline & $<3$ years & 1.14 & {$[0.88 ; 1.47]$} \\
\hline \multirow{2}{*}{$\begin{array}{l}\text { Time since } \\
\text { homeless }\end{array}$} & $>2$ years & ref & \\
\hline & $\leq 2$ years & 1.15 & {$[0.90 ; 1.49]$} \\
\hline \multirow{2}{*}{$\begin{array}{l}\text { Residential } \\
\text { instability }\end{array}$} & No & ref & \\
\hline & Yes & 1.00 & {$[0.74 ; 1.35]$} \\
\hline \multicolumn{4}{|c|}{ PHYSICAL HEALTH CHARACTERISTICS } \\
\hline \multirow{2}{*}{$\begin{array}{l}\text { Unmet health } \\
\text { needs, in the } \\
\text { preceding } 12 \\
\text { months }\end{array}$} & No & ref & \\
\hline & Yes & 1.68 & {$[1.09 ; 2.57]$} \\
\hline \multicolumn{4}{|c|}{ MENTAL HEALTH CHARACTERISTICS } \\
\hline \multirow{2}{*}{$\begin{array}{l}\text { Lifetime suicide } \\
\text { risk }\end{array}$} & No & ref & \\
\hline & Yes & 2.26 & {$[1.82 ; 2.82]$} \\
\hline \multirow{2}{*}{$\begin{array}{l}\text { PTSD, in the } \\
\text { preceding } 12 \\
\text { months }\end{array}$} & No & ref & \\
\hline & Yes & 1.97 & {$[1.50 ; 2.60]$} \\
\hline
\end{tabular}

Beardslee, 2014; Chambers et al., 2014), domestic violence (Bassuk, 2017; Vostanis et al., 2001; Bassuk and Beardslee, 2014; Chambers et al., 2014) or serious health problems (Chambers et al., 2014) were associated with depression. It may be that the experience of homelessness and population homogeneity trumped over other risk factors of depression.

\subsection{Limitations and strengths}

Our study has several limitations, which need to be discussed. First, ENFAMS is a cross-sectional survey which limits the possibility to establish the direction of associations between depression and certain characteristics. For instance, we are not able to determine whether unmet health needs or lack of social support are a consequence of depression or directly contribute to the worsening of mother's mental health. It is likely that these associations are bidirectional and that both phenomena are at play. Still, for certain characteristics associated with de- pression (e.g. PTSD), the cross-sectional design is not an issue as it most likely precedes the occurrence of depression. Second, insufficient statistical power and population homogeneity (most families were very poor and immigrant) may explain why some factors (e.g. food insecurity and employment status) were not associated with depression. Third, depression could be underestimated in this survey: some mothers could deny or not recognize their symptoms. This is especially an issue as most mothers participating in our study were immigrant and psychometric test may not be sufficient culturally sensitive (Sheehan et al., 1998; Baubet and Moro, 2013).

Nevertheless, our study has strengths which deserve to be highlighted. First, the ENFAMS survey includes a multicultural sample of homeless families, who are rarely studied. Our research fills a gap in the mental health literature by showing a high prevalence of depression and post-traumatic stress disorder among homeless mothers, who represent a diverse group in terms of region of origin, administrative status and living conditions. Second, we used validated measures of mental health (MINI (Sheehan et al., 1998) and CIDI (Kessler et al., 1998)), physical health and a large questionnaire examining mother's living and housing conditions. Furthermore, interviews were conducted by bilingual trained interviewers and psychologists in 17 different languages, making it possible to include a diverse sample of families.

\subsection{Policy implications}

Our research showing elevated levels of depression and other mental health problems among homeless families has several implications. First, housing policies and services must seek to re-house mothers in a timely fashion. Residential instability is associated with higher incidence of maternal depression and other psychiatric problems affecting homeless parents (Suglia et al., 2011). Interventions in this area, such as the "Housing first" program developed in Canada and experimented in France among persons who are homeless and experience severe psychiatric disorders, showed that persons who were offered stable housing had higher housing stability as well as quality of life and community functioning at a 2-year follow-up (Résumé du rapport final du project pancanadien Chez Soi, 2016). A recent study, conducted among individuals originating from Sub-Saharan Africa living in France showed that the risk of HIV infection was directly associated with unstable living circumstances upon arrival in France - suggesting that migrants' rapid access to legal documentation, housing and employment could help limit exposure to multiple health risks (Desgrees-du-Lou et al., 2016). Among homeless families, similar improvements could be expected (Karim et al., 2006).

Second, once families are housed and their urgent needs are addressed, policies must facilitate access to primary care and mental health care when needed (Lee et al., 2010). Few mothers in need of services receive mental health care, and the main point of contact for those with a mental health problem is the general practitioner (Zima et al., 1996). Our study shows high levels of unmet health needs among homeless mothers, suggesting that strategies which make it easier for them to access medical care (e.g. mobile clinics, outreach activities, combined mother and baby care, integrated services inside or close to their living premises (Perry et al., 2016), access to interpreters and trauma-specific psychotherapy (Bassuk and Beardslee, 2014)) should be developed.

Third, homeless families need global social and health care. Policies must set up specialized consultations integrating mental health care and welfare services for this vulnerable population (Guo et al., 2016; Keogh et al., 2015). An example of such services is Assertive Community Treatment (ACT), a team treatment approach designed to provide comprehensive, community-based psychiatric treatment, rehabilitation, and support to persons with serious and persistent mental illness developed in Canada (Perry and Craig, 2015). ACT teams provide: case man- 
Table 3

Characteristic associated with PTSD history in homeless women with depression in the Paris region (ENFAMS survey 2013, $\mathrm{n}=202$, univariate Poisson regression analysis).

\begin{tabular}{|c|c|c|c|c|c|}
\hline & & $\begin{array}{l}\text { Concomittant PTSD }(\mathrm{n}= \\
\text { 75) }\end{array}$ & $\begin{array}{l}\text { Past history of PTSD ( } \mathrm{n} \\
=24 \text { ) }\end{array}$ & $\begin{array}{l}\text { No PTSD }(n= \\
103)\end{array}$ & $\mathrm{p}$ \\
\hline \multicolumn{6}{|l|}{ SOCIO DEMOGRAPHIC CHARACTERISTICS } \\
\hline \multirow[t]{2}{*}{ Reason for departure from country of origin } & $\begin{array}{l}\text { Not a violent } \\
\text { cause }\end{array}$ & 48.2 & 70.9 & 84.3 & $\begin{array}{l}< \\
0.001\end{array}$ \\
\hline & Violent cause & 51.8 & 29.1 & 15.7 & \\
\hline \multirow[t]{3}{*}{ Health insurance } & Complete & 66 & 51.8 & 68.4 & 0.035 \\
\hline & Incomplete & 4.4 & 18.6 & 18.3 & \\
\hline & None & 29.6 & 29.6 & 13.3 & \\
\hline \multirow[t]{2}{*}{ Social support } & Yes & 23.5 & 39.8 & 58.5 & $\begin{array}{l}< \\
0.001\end{array}$ \\
\hline & No & 76.5 & 60.2 & 41.5 & \\
\hline \multicolumn{6}{|l|}{ LIVING AND HOUSING CONDITIONS } \\
\hline \multirow[t]{2}{*}{ Ever spend the night in the street } & No & 72.8 & 97.1 & 80.9 & 0.025 \\
\hline & Yes & 27.2 & 2.9 & 19.1 & \\
\hline \multicolumn{6}{|l|}{ PHYSICAL HEALTH CHARACTERISTICS } \\
\hline \multirow{2}{*}{$\begin{array}{l}\text { Serious health problem(s) that has(ve) } \\
\text { disrupted daily life }\end{array}$} & No & 49.4 & 61.7 & 72.7 & 0.03 \\
\hline & Yes & 50.6 & 38.3 & 27.3 & \\
\hline \multirow[t]{2}{*}{ Pregnancy } & No & 82 & 96 & 96.5 & 0.007 \\
\hline & Yes & 18 & 4 & 3.5 & \\
\hline \multicolumn{6}{|l|}{ MENTAL HEALTH CHARACTERISTICS } \\
\hline \multirow{2}{*}{ Lifetime suicide risk } & No & 46.2 & 54.8 & 69.9 & 0.039 \\
\hline & Yes & 53.8 & 45.2 & 30.1 & \\
\hline
\end{tabular}

Among mothers with depression and concomittant PTSD, 51.8\% have leaved their country for a violent cause.

agement, initial and ongoing assessments; psychiatric services; employment and housing assistance; family support and education; substance abuse services; and other services and supports critical to an individual's ability to live successfully in the community. Our results stress the role of health professionals in addressing the mental health needs of this population, especially in case of residential instability and homelessness. Supporting preventive and therapeutic interventions with homeless mothers and children, and adapting services to meet the needs of this vulnerable population are essential to ameliorate mental health among mothers and improve their and their children's social and health outcomes.

\section{Conclusion}

Homeless mothers have high levels of depression, which are partly related to other psychiatric comorbidities such as post-traumatic stress disorder. Rehousing families and improving their access to health services could improve the mental health of mothers and limit the impact on their children.

\section{Acknowledgements}

We thank all the families involved in ENFAMS survey.

\section{Author statement}

All persons who meet authorship criteria are listed as authors, and all authors certify that they have participated sufficiently in the work to take public responsibility for the content, including participation in the concept, design, analysis, writing, or revision of the manuscript. Furthermore, each author certifies that this material or similar material has not been and will not be submitted to or published in any other publication before.

\section{Role of the funding source}

Financers fund the ENFAMS survey, not this study. Funding have not influenced conception and design of this study, they have not participated to acquisition of data and they have not contributed in analy- sis and/or interpretation of data, drafting the manuscript, revising the manuscript and in the decision to submit the article for publication. This funding made it possible to be independent of the Samu Social. ENFAMS survey was conducted by the Observatoire du Samu Social which is independent of the Samu Social.

\section{References}

Alltag S. Stein J. Pabst A. Weyerer S. Werle J. Maier W. et al., 2017. Unmet needs in the depressed primary care elderly and their relation to severity of depression: results from the AgeMooDe study Aging Ment. Health 1-8 https://doi.org/10.1080/ 13607863.2017.1328480

An overview of housing exclusion in europe, 2015. FEANTSA

Bassuk E.L. Intimate Partner Violence in Extremely Poor Women: Longitudinal Patterns and Risk Markers. ResearchGate n.d. 〈https://www.researchgate.net/publication/ 226252459_Intimate_Partner_Violence_in_Extremely_Poor_Women_Longitudinal_ Patterns and Risk $>$ Markers (Accessed 1 August 2017).

Bassuk E.L. Beardslee W.R. 2014. Depression in homeless mothers: addressing an unrecognized public health issue Am. J. Orthopsychiatry 84 73-81 https://doi.org/10.1037/ h0098949

Bassuk E.L., Perloff J., Dawson R. Multiply homeless families: The insidious impact of violence. Hous Policy Debate n.d.;12:299-320.

Bassuk E.L. Buckner J.C. Perloff J.N. Bassuk S.S. 1998. Prevalence of mental health and substance use disorders among homeless and low-income housed mothers Am. J. Psychiatry 155 1561-1564

Bassuk E.L., DeCandia C.J., Beach C.A., Berman F., 2014. America's Youngest Outcasts: A Report Card on Child Homelessness. Waltham, MA.: The National Center on Family Homelessness at American Institutes for Research.

Baubet T. Moro M.-R. 2013. L'évaluation clinique en situation transculturelle - Les Biais en situation transculturelle. Psychopathol. Transcult Elsevier Masson 114-118

Bernstein, A.B., 2001. Motherhood, health status, and health care Women's. Health Issues 11, 173-184. https://doi.org/10.1016/S1049-3867(01)00078-0.

Bernstein, K.S., Park, S.-Y., Shin, J., Cho S. Park Y. 2011. Acculturation, discrimination and depressive symptoms among Korean immigrants in New York City. Community Ment. Health J. 47, 24-34. https://doi.org/10.1007/s10597-009-9261-0.

Boyce, P., Parker, G., Barnett, B., Cooney, M., Smith, F., 1991. Personality as a vulnerability factor to depression. Br. J. Psychiatry J. Ment. Sci. 159, 106-114.

Breslau N. Davis G.C. Peterson E.L. Schultz L.R. 2000. A second look at comorbidity in victims of trauma: the posttraumatic stress disorder-major depression connection Biol. Psychiatry 48 902-909

Brown G.W. Moran P.M. 1997. Single mothers, poverty and depression Psychol. Med. 27 21-33

Brown G.W. Harris T.O. Hepworth C. 1995. Loss, humiliation and entrapment among women developing depression: a patient and non-patient comparison Psychol. Med 25 7-21

Buckner J.C. Beardslee W.R. Bassuk E.L. 2004. Exposure to violence and low-income children's mental health: direct, moderated, and mediated relations Am. J. Orthopsychiatry 74 413-423 https://doi.org/10.1037/0002-9432.74.4.413 
Caspi A. McClay J. Moffitt T.E. Mill J. Martin J. Craig I.W. et al., 2002. Role of genotype in the cycle of violence in maltreated children Science $297851-854$ https://doi.org/ $10.1126 /$ science. 1072290

Caspi A. Sugden K. Moffitt T.E. Taylor A. Craig I.W. Harrington H. et al., 2003. Influence of life stress on depression: moderation by a polymorphism in the 5-HTT gene Science 301 386-389 https://doi.org/10.1126/science.1083968

Caspi, A., Moffitt, T.E., Cannon, M., McClay, J., Murray, R., Harrington, H., et al., 2005. Moderation of the effect of adolescent-onset cannabis use on adult psychosis by a functional polymorphism in the catechol-O-methyltransferase gene: longitudinal evidence of a gene X environment interaction. Biol. Psychiatry 57, 1117-1127. https://doi.org/ 10.1016/j.biopsych.2005.01.026

Chambers C. Chiu S. Scott A.N. Tolomiczenko G. Redelmeier D.A. Levinson W. et al., 2014. Factors associated with poor mental health status among homeless women with and without dependent children Community Ment. Health J. $50553-559$ https://doi.org/ 10.1007/s10597-013-9605-7

Chan Chee C., Beck F., Sapinho D., Guilbert P., 2009. La dépression en France - Enquête Anadep 2005. Saint Denis: INPES.

Cutler S.E. Nolen-Hoeksema S. 1991. Accounting for sex differences in depression through female victimization: childhood sexual abuse Sex Roles 24 425-438 https://doi.org/ 10.1007/BF00289332

Desgrees-du-Lou A. Pannetier J. Ravalihasy A. Le Guen M. Gosselin A. Panjo H. et al., 2016. Is hardship during migration a determinant of HIV infection? Results from the ANRS PARCOURS study of sub-Saharan African migrants in France AIDS Lond. Engl. 30 645-656 https://doi.org/10.1097/QAD.0000000000000957

Eley T.C. Sugden K. Corsico A. Gregory A.M. Sham P. McGuffin P. et al., 2004. Gene-environment interaction analysis of serotonin system markers with adolescent depression Mol. Psychiatry 9 908-915 https://doi.org/10.1038/sj.mp.4001546

Gertz J. Varley K.E. Reddy T.E. Bowling K.M. Pauli F. Parker S.L. et al., 2011. Analysis of DNA methylation in a three-generation family reveals widespread genetic influence on epigenetic regulation PLoS Genet 7 e1002228 https://doi.org/10.1371/journal.pgen. 1002228

Gilbert P. Allan S. 1998. The role of defeat and entrapment (arrested flight) in depression: an exploration of an evolutionary view Psychol. Med. 28 585-598

Gillespie, N.A., Whitfield, J.B., Williams, B., Heath, A.C., Martin, N.G., 2005. The relationship between stressful life events, the serotonin transporter (5-HTTLPR) genotype and major depression. Psychol. Med. 35, 101-111.

Goodman L.A. Smyth K.F. Borges A.M. Singer R. 2009. When crises collide: how intimate partner violence and poverty intersect to shape women's mental health and coping? Trauma Violence Abus. 10 306-329 https://doi.org/10.1177/1524838009339754

Grant R. Gracy D. Goldsmith G. Shapiro A. Redlener I.E. 2013. Twenty-five years of child and family homelessness: where are we now? Am J Public Health 103 (Suppl 2), e1-10 https://doi.org/10.2105/AJPH.2013.301618

Guo X. Slesnick N. Feng X. 2016. Housing and support services with homeless mothers: benefits to the mother and her children Community Ment. Health J. 52 73-83 https: //doi.org/10.1007/s10597-015-9830-3

Gupta A. Leong F. Valentine J.C. Canada D.D. 2013. A meta-analytic study: the relationship between acculturation and depression among Asian Americans Am. J. Orthopsychiatry 83 372-385 https://doi.org/10.1111/ajop.12018

Guyavarch E., Le Mener E., 2010. Connaissances sur les personnes en famille sans logement personnel.

Hamel C. Brown E. Cavalin C. Cromer S. Debauche A. Lebugle A. et al., 2014. Enquête VIRAGE Violences et rapports de genre: Contextes et conséquences des violences subies par les femmes et les hommes

Henderson A. 1992. Social support and depression Mean. Meas. Soc. Suppor. Hemisphere Veiel H, Bau- mann U New York 85-92

Holmes S.J. Robins L.N. 1988. The role of parental disciplinary practices in the development of depression and alcoholism Psychiatry 51 24-36

Holt R.I.G. de Groot M. Golden S.H. 2014. Diabetes and depression Curr. Diabetes Rep. 14 491 https://doi.org/10.1007/s11892-014-0491-3

Huizink A.C. Mulder E.J.H. Buitelaar J.K. 2004. Prenatal stress and risk for psychopathology: specific effects or induction of general susceptibility? Psychol. Bull. 130 115-142 https://doi.org/10.1037/0033-2909.130.1.115

Janssen-Kallenberg H. Schulz H. Kluge U. Strehle J. Wittchen H.-U. Wolfradt U. et al., 2017. Acculturation and other risk factors of depressive disorders in individuals with Turkish migration backgrounds BMC Psychiatry 17 https://doi.org/10.1186/ s12888-017-1430-z

Karim K. Tischler V. Gregory P. Vostanis P. 2006. Homeless children and parents: short-term mental health outcome Int J. Soc. Psychiatry 52 447-458

Kaufman J. Plotsky P.M. Nemeroff C.B. Charney D.S. 2000. Effects of early adverse experiences on brain structure and function: clinical implications Biol. Psychiatry 48 778-790

Kendler, K.S., Gardner, C.O., Prescott, C.A., 2002. Toward a comprehensive developmental model for major depression in women. Am. J. Psychiatry 159, 1133-1145. https: //doi.org/10.1176/appi.ajp.159.7.1133.

Kendler, K.S., Hettema, J.M., Butera, F., Gardner, C.O., Prescott, C.A., 2003. Life event dimensions of loss, humiliation, entrapment, and danger in the prediction of onsets of major depression and generalized anxiety. Arch. Gen. Psychiatry 60, 789-796. https: //doi.org/10.1001/archpsyc.60.8.789.

Kendler, K.S., Kuhn, J.W., Vittum, J., Prescott, C.A., Riley, B., 2005. The interaction of stressful life events and a serotonin transporter polymorphism in the prediction of episodes of major depression: a replication. Arch. Gen. Psychiatry 62, 529-535. https: //doi.org/10.1001/archpsyc.62.5.529.
Keogh, C., O'Brien, K.K., Hoban, A., O'Carroll, A., Fahey, T., 2015. Health and use of health services of people who are homeless and at risk of homelessness who receive free primary health care in Dublin. BMC Health Serv. Res. 15, 58. https://doi.org/10. 1186/s12913-015-0716-4.

Kessler,

1997 R.C. Kessler, The effects of stressful life events on depression, Annu Rev. Psychol. 48 (1997) 191-214, https://doi.org/10.1146/annurev.psych.48.1.191.

Kessler, R.C., Magee, W.J., 1993. Childhood adversities and adult depression: basic pat terns of association in a US national survey. Psychol. Med. 23, 679-690.

Kessler, R.C., Nelson, C.B., McGonagle, K.A., Liu, J., Swartz, M., Blazer, D.G., 1996. Comorbidity of DSM-III-R major depressive disorder in the general population: results from the US National Comorbidity Survey. Br. J. Psychiatry Suppl. 17-30.

Kessler, R.C., Wittchen, H.-U., Abelson, J.M., Mcgonagle, K., Schwarz N. Kendler K.S. et al., 1998. Methodological studies of the Composite International Diagnostic Interview (CIDI) in the US national comorbidity survey (NCS). Int J. Methods Psychiatr. Res 7, 33-55. https://doi.org/10.1002/mpr.33.

de Kloet, E.R., Joëls, M., Holsboer, F., 2005. Stress and the brain: from adaptation to disease. Nat. Rev. Neurosci. 6, 463-475. https://doi.org/10.1038/nrn1683.

Laporte, A., Douay, C., Détrez, M.-A., Le Masson, V., Le Mener, E., Chauvin, P., 2010. La santé mentale et les addictions chez les personnes sans logement personnel d'île-de-France (Samenta). Observatoire du Samusocial. INSERM.

Laporte A., Le Mener E., Détrez M.-.A., Douay C., Le Strat Y., Vandentorren S.. et al. 2015 Mental health and addictions among homeless in the Paris metropolitan area: the SAMENTA survey in 2009. BEH Bull Epidémiologie Hebd.

Lee, S., Castella, A., de, Freidin, J., Kennedy A. Kroschel J. Humphrey C. et al., 2010. Mental health care on the streets: an integrated approach. Aust. N. Z. J. Psychiatry 44, 505-512. https://doi.org/10.3109/00048670903555120.

Lee S.S. August G.J. Gewirtz A.H. Klimes-Dougan B. Bloomquist M.L. Realmuto G.M. 2010 Identifying unmet mental health needs in children of formerly homeless mothers living in a supportive housing community sector of care J. Abnorm Child Psychol. 38 421-432 https://doi.org/10.1007/s10802-009-9378-1

Leon, L., Jauffret-Roustide, M., Le Strat, Y., 2015. Design-based inference in time-location sampling. Biostat. Oxf. Engl. 16, 565-579. https://doi.org/10.1093/biostatistics/ kxu061.

Martin-Fernandez, J., Grillo, F., Parizot, I., Caillavet, F., Chauvin, P., 2013. Prevalence and socioeconomic and geographical inequalities of household food insecurity in the Paris region, France, 2010. BMC Public Health 13, 486. https://doi.org/10.1186/ 1471-2458-13-486.

Monroe S.M. Harkness K.L. 2005. Life stress, the "kindling" hypothesis, and the recurrence of depression: considerations from a life stress perspective Psychol. Rev. 112 417-445 https://doi.org/10.1037/0033-295X.112.2.417

O'Donnell M.L. Creamer M. Pattison P. 2004. Posttraumatic stress disorder and depression following trauma: understanding comorbidity Am. J. Psychiatry 161 1390-1396 https://doi.org/10.1176/appi.ajp.161.8.1390

Pannetier J. Lert F. Jauffret Roustide M. du Loû A.D. 2017. Mental health of sub-saharan african migrants: the gendered role of migration paths and transnational ties SSM Popul Health 3 549-557 https://doi.org/10.1016/j.ssmph.2017.06.003

Parker G. 1979. Parental characteristics in relation to depressive disorders Br. J. Psychiatry J. Ment. Sci. 134 138-147

Perry J. Craig T.K.J. 2015. Homelessness and mental health Trends Urol. Men's Health 6 19-21 https://doi.org/10.1002/tre.445

Perry N.S. Huebner D.M. Baucom B.R. Hoff C.C. 2016. Relationship power, sociodemographics, and their relative influence on sexual agreements among gay male couples AIDS Behav. 20 1302-1314 https://doi.org/10.1007/s10461-015-1196-6

Phillips M.L. Drevets W.C. Rauch S.L. Lane R. 2003. Neurobiology of emotion perception I: the neural basis of normal emotion perception Biol. Psychiatry 54 504-514

Phillips M.L. Drevets W.C. Rauch S.L. Lane R. 2003. Neurobiology of emotion perception II: implications for major psychiatric disorders Biol. Psychiatry 54 515-528

Radimer, K.L., 2002. Measurement of household food security in the USA and other industrialised countries. Public Health Nutr. 5, 859-864. https://doi.org/10.1079/ PHN2002385.

Résumé du rapport final du project pancanadien Chez Soi. Ment Health Comm Can n.d. 〈http://www.mentalhealthcommission.ca/Francais/document/27511/ executive-summary-cross-site-homechez-soi-project) (Accessed 9 February 2016).

Roze M., Melchior M., Chauvin P., Rezzoug D., Baubet T., Vandentorren S., 2017. Post-Traumatic Stress Disorders in homeless migrant women in the Paris region. Results of the ENFAMS survey. Eur Psychiatry Submitt Manuscr.

Sheehan, D.V., Lecrubier, Y., Sheehan, K.H., Amorim, P., Janavs, J., Weiller, E., et al., 1998. The Mini-International Neuropsychiatric Interview (M.I.N.I.): the development and validation of a structured diagnostic psychiatric interview for DSM-IV and ICD-10. J. Clin. Psychiatry 59 (Suppl 20), 22-33-57.

Suglia S.F. Duarte C.S. Sandel M.T. 2011. Housing quality, housing instability, and maternal mental health J. Urban Health Bull. N. Y. Acad. Med 88 1105-1116 https://doi org/10.1007/s11524-011-9587-0

Sweetland, A.C., Belkin, G.S., Verdeli, H., 2014. Measuring depression and anxiety in sub-saharan Africa. Depress. Anxiety 31, 223-232. https://doi.org/10.1002/da. 22142 .

Tsai, A.C., 2015. Socioeconomic gradients in internalized stigma among 4,314 persons with HIV in sub-Saharan Africa. AIDS Behav. 19, 270-282. https://doi.org/10.1007/ s10461-014-0993-7.

Ünlü Ince, B., Fassaert, T., de Wit, M.A., Cuijpers, P., Smit, J., Ruwaard, J., et al., 2014. The relationship between acculturation strategies and depressive and anxiety disor- 
ders in Turkish migrants in the Netherlands. BMC Psychiatry 14. https://doi.org/10.1186/ s12888-014-0252-5.

van Buuren, S., Groothuis-Oudshoorn, K., 2011. MICE: multivariate Imputation by Chained Equations in R. J. Stat. Softw. 45. https://doi.org/10.18637/jss.v045.i03.

Vandentorren, S., Le Méner, E., Oppenchaim, N., Arnaud, A., Jangal C. Caum C. et al., 2016. Characteristics and health of homeless families: the ENFAMS survey in the Paris region, France 2013. Eur. J. Public Health 26, 71-76. https://doi.org/10.1093/ eurpub/ckv187.

Vostanis, P., Tischler, V., Cumella, S., Bellerby, T., 2001. Mental health problems and social supports among homeless mothers and children victims of domestic and community violence. Int. J. Soc. Psychiatry 47, 30-40.

Vuillermoz, C., Vandentorren, S., Brondeel, R., Chauvin, P., 2017. Unmet healthcare needs in homeless women with children in the Greater Paris area in France. PLoS One 12, e0184138. https://doi.org/10.1371/journal.pone.0184138.

Weinreb, L.F., Buckner J.C. Williams V. Nicholson J. 2006. A comparison of the health and mental health status of homeless mothers in Worcester, Mass: 1993 and 2003. Am. J. Public Health 96, 1444. https://doi.org/10.2105/AJPH.2005.069310.
Willner, P., 2017. The chronic mild stress (CMS) model of depression: history, evaluation and usage. Neurobiol. Stress 6, 78-93https://doi.org/10.1016/j.ynstr.2016.08 002.

York, T.P., Miles, M.F., Kendler K.S. Jackson-Cook C. Bowman M.L. Eaves L.J. 2005 Epistatic and environmental control of genome-wide gene expression. Twin Res. Hum. Genet J. Int. Soc. Twin Stud. 8, 5-15. https://doi.org/10.1375/1832427053435418.

Zabkiewicz, D.M., Patterson, M., Wright, A., 2014. A cross-sectional examination of the mental health of homeless mothers: does the relationship between mothering and mental health vary by duration of homelessness?. BMJ Open 4, e006174. https://doi. org/10.1136/bmjopen-2014-006174.

Zima, B.T., Wells, K.B., Benjamin, B., Duan, N., 1996. Mental health problems among homeless mothers: relationship to service use and child mental health problems. Arch. Gen. Psychiatry 53, 332-338.

Zou, G., 2004. A modified poisson regression approach to prospective studies with binary data. Am. J. Epidemiol. 159, 702-706. 